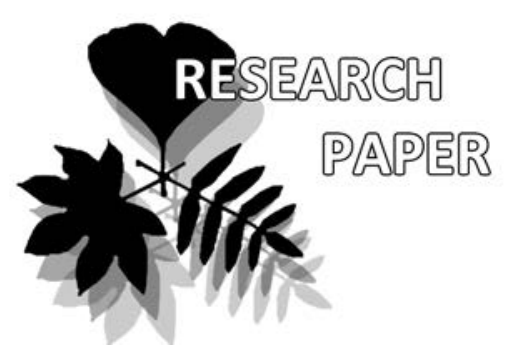

\title{
Interspecific variation in foliar nutrients and isotopes of submerged macrophytes in the Cau Hai Lagoon, the typical brackish lagoon in Vietnam
}

Dang Thi Nhu Y ${ }^{1,2 *}$, Nguyen Tien Hoang ${ }^{7}$, Pham Khac Lieu ${ }^{3}$, Hidenori Harada ${ }^{5}$, Keisuke Koba ${ }^{4}$ Natacha Brion ${ }^{6}$, Duong Van Hieu ${ }^{8}$, Nguyen Van Hop ${ }^{8}$, Tim Sierens ${ }^{1} \&$ Harry Olde Venterink ${ }^{1}$,

Dang Thi Nhu $\mathrm{Y}^{1,2 *}$

e-mail: y.dang@vnuk.edu.vn

Nguyen Tien Hoang 7

e-mail: nguyenhoanggis@gmail.com

Pham Khac Lieu ${ }^{3}$

e-mail: pklieu@hueuni.edu.vn

Hidenori Harada ${ }^{5}$

e-mail: harada.hidenori.8v@kyoto-u.ac.jp

Keisuke $\mathrm{Koba}^{4}$

e-mail: keikoba@ecology.kyoto-u.ac.jp

Natacha Brion ${ }^{6}$

e-mail: nnbrion@vub.be

Duong Van $\mathrm{Hieu}^{8}$

e-mail:dvhieu@hueuni.edu.vn

Nguyen Van Hop ${ }^{8}$

e-mail: nvanhop@hueuni.edu.vn

Tim Sierens

e-mail: Timothy.Sierens@vub.be

Harry Olde Venterink

e-mail: Harry.Olde.Venterink@vub.be

${ }^{1}$ Department of Biology, Vrije Universiteit Brussel (VUB), Brussels, Belgium

${ }^{2}$ VNUK Institute for Research and Executive Education, The University of Danang, 158A Le Loi Street, Hai Chau District, Danang, Vietnam

${ }^{3}$ Department of Science, Technology and Environment, Hue University, Hue, Vietnam

${ }^{4}$ Center for Ecological Research, Kyoto University, Otsu, Shiga 520-2113, Japan

${ }^{5}$ Graduate School of Global

Environmental Studies, Kyoto University, Kyoto 606-8501, Japan

${ }^{6}$ Analytical, Environmental and Geochemistry, Vrije Universiteit Brussel (VUB), Brussels, Belgium

${ }^{7}$ Laboratory of Environmental Geosphere Engineering, Department of Urban

Management, Graduate School of

Engineering, Kyoto University, Kyoto 615-8540, Japan

${ }^{8}$ College of Sciences, Hue University, Hue, Vietnam

* corresponding author

Manuscript received: 04.05 .2020

Review completed: 15.07.2020

Accepted for publication: 22.07 .2020

Published online: 25.07.2020

\begin{abstract}
A B S T R A C T
Submersed macrophytes are key elements of shallow coastal ecosystems but globally declined due to anthropogenic disturbances and climate change. Foliar elemental and isotopic compositions of macrophytes are being increasingly used to identify nutritional status and environmental conditions including potential stress factors, thereto insight is required in its interspecific variation. In this paper, we present interspecific variations in foliar nutrients $(\mathrm{C}, \mathrm{N}, \mathrm{P})$ and stable isotopes $\left(\delta^{13} \mathrm{C}\right.$ and $\delta^{15} \mathrm{~N}$ ) of four macrophyte species (Najas indica, Halophila beccarii, Halodule uninervis, Halophila ovalis) in Cau Hai lagoon (Vietnam) in relation to key environmental variables. The foliar $\mathrm{C}, \mathrm{N}, \delta^{13} \mathrm{C}$ and $\delta^{15} \mathrm{~N}$ values varied among species and related to salinity, water depth and/or DIN concentrations. Foliar $\mathrm{N}$ and $\mathrm{C}: \mathrm{N}$ values were correlated to DIN concentration in the water (N. indica and H. beccarii, respectively), whereas foliar C:P was correlated to P concentrations in sediment ( $N$. indica) or water depth $\left(H\right.$. uninervis). Foliar $\delta^{13} \mathrm{C}$ of $H$. beccarii and $H$. uninervis increased with salinity and $\delta^{15} \mathrm{~N}$ of $N$. indica with both salinity and DIN concentration in the water. These aquatic plants likely varied either in resource acquisition strategies (e.g. uptake of $\mathrm{CO}_{2}$ or $\mathrm{HCO}_{3}^{-}, \mathrm{N}$ and $\mathrm{P}$ from different sources) or in their usage (e.g. $\mathrm{C}$ investment in structural tissue) and in their response to changes in salinity, water depth and DIN concentration in the water. The studied macrophytes likely experienced relatively high $\mathrm{N}$ and $\mathrm{P}$ availability and another factor than $\mathrm{P}$ or $\mathrm{N}$ probably inhibited C-fixation and/or carbon storage of these plants.
\end{abstract}

K e y w o r d s : Najas, Halophila, Halodule, salinity, depth, DIN, phosphorus

\section{P E 3 Ю M E}

Аанг Ти Нху И, Нгуен Тиен Хоанг, Фам Хак Аию, Харада Х., Коба К., Брион Н., Ван Хью А., Ван Хоп Н., Сиренз Т., Вентеринк Г.О. МежвиАовая изменчивость Аистовых питательных веществ и изотопов погруженных видов макрофитов в типичной сомоноватой магуне. Погруженные макрофиты являются кАючевыми компонентами мелководных прибрежных экосистем. В глобальном масштабе их сообщества существенно сократились из-за антропогенных нарушений и изменения климата. Элементные и изотопные составы Аистьев макрофитов все чаще используются Аля опреАеления их пищевого статуса и условий окружающей среАЫ, вкАючая потенциальные стрессовые факторы, Аля чего необходимо понимание их межвидовой изменчивости. В настоящей работе мы представляем результаты исследования межвидовых вариаций внекорневых питательных веществ (C, $\mathrm{N}$, Р) и стабильных изотопов $\left(\delta^{13} \mathrm{C}\right.$ и $\left.\delta^{15} \mathrm{~N}\right)$ четырех видов макрофитов: Najas indica, Halophila beccarii, Halodule uninervis, Halophila ovalis в магуне Кау-Хай (Вьетнам) в зависимости от кАючевых переменных окружающей среды. Содержания С, $\mathrm{N}$, значения $\delta^{13} \mathrm{C}$ и $\delta^{15} \mathrm{~N}$ варьировали в зависимости от вила и были связаны с соленостью, глубиной воды и или концентрацией DIN. Содержание N и значения C:N коррелировали с концентрацией DIN в воде у N. indica и H. beccarii, тогда как значения C:P коррелировали с концентрацией Р в детрите (N. indica) или в толще воды $\left(H\right.$. uninervis). $\delta^{13} \mathrm{C}$ у $H$. beccarii и $H$. uninervis увеличивалась с повышением солености, а $\delta^{15} \mathrm{~N}$ у $\mathrm{N}$. indica - как с повышением солености, так и с концентрацией DIN в воде. Макрофиты различались в стратегиях потребления ресурсов (например, поглощение $\mathrm{CO}_{2}$ или $\mathrm{HCO}_{3}^{-}$, $\mathrm{N}$ и $\mathrm{P}$ из различных источников), в их использовании (например, инвестиции С в структурные ткани), а также по их реакции на изменения солености, глубины воды и концентрации DIN в воде. Изученные макрофиты находились в условиях Аоступности $\mathrm{N}$ и $\mathrm{P}$, а фиксация С ингиборововалась Аругими факторами.

КАючевые слова: Najas, Halopbila, Halodule, соленость, глубина, DIN, фосфор

(переведено редколлегией)

Submersed macrophytes constitute key elements of shallow coastal ecosystems, but they are currently declining at an alarming rate (globally $7 \%$ per year according to Waycott et al. 2009). This decline is partly due to nutrient enrichment in aquatic ecosystems worldwide (Paerl 2009, Van Katwijk et al. 2011). Elemental 
and isotopic compositions of macrophyte leaves provide insight into the environmental conditions and availability of essential resources (N, P and light) for growth of aquatic plants and/or to detect stressors (shading, high salinity and high temperature) that predict an upcoming macrophyte decline (Fourqurean et al. 2007, Walton et al. 2016). Therefore, it is important to have insight in the variation in foliar concentrations of the key elements such as carbon (C), nitrogen $(\mathrm{N})$, phosphorus $(\mathrm{P})$ and their ratios - among species, as well as in relation to important environmental factors.

Nutrient $(\mathrm{N}$ and $\mathrm{P}$ ) concentrations in water and sediment as well as water depth, salinity, temperature and light conditions are considered to be key factors in controlling submerged macrophyte distribution, growth and foliar C, $\mathrm{N}$ and P concentrations (Hoyer et al. 2004, Ferdie \& Fourqurean 2004, Campbell \& Fourqurean 2009). Foliar concentrations of $\mathrm{C}, \mathrm{N}, \mathrm{P}$ and their ratios depend on the relative availability of $\mathrm{N}$ and $\mathrm{P}$ in water and sediment and on the macrophyte growth, which also depend on $\mathrm{C}$ assimilation during photosynthesis and hence on light and other growth limiting resources (Fourqurean et al. 2007). The benthic macrophyte Redfield Ratio C:N:P of 550:30:1 (molar base) has been used as an indicator for light, $\mathrm{N}$ or $\mathrm{P}$ limitation of macrophyte growth (Atkinson \& Smith 1983, Johnson et al. 2006), although some authors have debated the use of this ratio (Ferdie \& Fourqurean 2004, Walton et al. 2016). Plants growing in nutrient poor waters display significantly higher C:N and/or C:P ratios than those from nutrient rich conditions, provided they receive sufficient light (Atkinson \& Smith 1983).

Stable isotope signatures of $\mathrm{C}$ and $\mathrm{N}$ in macrophyte tissues have been used to elucidate the sources and relative availability of C and N (Anderson \& Fourqurean 2003, Lepoint et al. 2004, Campbell \& Fourqurean 2009) as well as light condition in their habitats (Gorman et al. 2017). Generally, the ${ }^{13} \mathrm{C}$ values in seagrasses range from $-23 \%$ to $-3 \% 0$ (Anderson \& Fourqurean 2003). This large variation can be ascribed to interspecific differences in discrimination against the heavier ${ }^{13} \mathrm{C}$ isotope during photosynthetic fixation of $\mathrm{CO}_{2}$ (Lepoint et al. 2004, West et al. 2006) or variations in $\delta^{13} \mathrm{C}$ of the available carbon sources $\left(\mathrm{CO}_{2}\right.$ and $\left.\mathrm{HCO}_{3}^{-}\right)$ (Falkowski et al. 1989). Hence, the variation in foliar $\delta^{13} \mathrm{C}$ also depends on light conditions and ambient temperature which influence the photosynthetic rate (Campbell \& Fourqurean 2013, Fourqurean et al. 2015), or factors which affect $\mathrm{HCO}_{3}^{-}$availability, such as salinity (Fry 2002). Plants that assimilate $\mathrm{HCO}_{3}^{-}$for photosynthesis are more enriched in $\delta^{13} \mathrm{C}$ compared to those that assimilate $\mathrm{CO}_{2}$, because $\mathrm{HCO}_{3}^{-}$ has a less negative $\delta^{13} \mathrm{C}$ than $\mathrm{CO}_{2}(0 \%$ vs. $-9 \%$ ) (Raven et al. 2002, Chappuis et al. 2017). Thus, submerged plants have enriched values of $\delta^{13} \mathrm{C}(-16.7 \% 0$ to $-10.5 \%)$ in comparison to aquatic plants with leaves in contact with the atmosphere (-34.8\%o to $-14.6 \%$ ) (Chappuis et al. 2017). The $\delta^{15} \mathrm{~N}$ values in macrophytes range from $-5.2 \%$ to $20.1 \%$ (Chappuis et al. 2017), with tropical macrophyte genera including Halodule spp., Halophila spp. and Syringodium spp. being among the most depleted (Fourqurean et al. 2015, Walton et al. 2016). Foliar $\delta^{15} \mathrm{~N}$ is affected by $\mathrm{N}$ sources and plant acquisition mechanisms (Sun et al. 2011, Peipoch et al. 2014, Walton et al. 2016). The use of $\delta^{15} \mathrm{~N}$ in aquatic plants to distinguish between natural and sewage derived $\mathrm{N}$ is well documented (Risk et al. 2009). A high foliar $\delta^{15} \mathrm{~N}$ (above $5 \%$ ) in macrophytes indicates that the acquired $\mathrm{N}$ associated to human and animal waste inputs (Yamamuro et al. 2003, Connolly et al. 2013, Fourqurean et al. 2015). Instead, low foliar $\delta^{15} \mathrm{~N}$ values $(\sim 0 \%)$ in macrophytes documents that $\mathrm{N}$ was derived from nitrate (fertilizer), from re-mineralised $\mathrm{N}$ from locally produced organic matter, or from $\mathrm{N}$ derived from atmospheric $\mathrm{N}_{2}$ fixation (Peipoch et al. 2013, Fourqurean et al. 2015, Walton et al. 2016). Negative $\delta^{15} \mathrm{~N}$ values in plants can indicate that $\mathrm{N}$ was derived from nitrification (Yu et al. 2015) or to mycorrhizal associations (Hobbie et al. 2005). Hence, proportion of $\mathrm{C}$ and $\mathrm{N}$ isotopes in macrophytes can reflect the availability of essential resources and provide insight in their growth conditions (Campbell \& Fourqurean 2009). However, knowledge about interspecific differences and the effects of environmental factors on isotope ratios is still limited for many seagrasses and macrophytes.

Although there are many studies that have evaluated variation in foliar nutrients of submerged macrophyte species such as Halodule uninervis, Halophila ovalis (Yamamuro et al. 2003, Campbell \& Fourqurean 2009, Walton et al. 2016), there is still limited information about elemental and isotopic compositions of Najas indica and Halophila beccarii so far. Additionally, the effects of environmental factors in tropical lagoons on such differences are still limited. In this study, we examined interspecific variation in foliar nutrients $(\mathrm{C}, \mathrm{N}$, and $\mathrm{P})$ and stable isotopes $\left(\delta^{13} \mathrm{C}\right.$ and $\left.\delta^{15} \mathrm{~N}\right)$ of four macrophyte species in Cau Hai lagoon (Vietnam) in relation to key environmental variables (such as salinity, water depth or nutrient concentrations in water and sediment). This is the first attempt to characterize the sources of variation in elemental and isotope ratios of these submerged macrophyte species and discuss role of ecological and/ or physiological characteristics in a tropical monsoon lagoon. We focused on the four macrophyte species Najas indica (Willd.) Cham., Halophila beccarii Aschers., Halodule uninervis (Forssk.) Boiss. and Halophila ovalis (R. Br.) Hook. f. which are common in Cau Hai lagoon, but internationally considered as threatened species (Short et al. 2011, Odelu et al. 2014). Although N. indica is generally classified as a freshwater macrophyte, it is quite abundant in the Cau Hai lagoon and usually forms mixed beds with $H$. beccarii.

\section{MATERIAL AND METHODS Study site}

The Cau Hai lagoon $\left(16^{\circ} 19^{\prime} 22^{\prime \prime} \mathrm{N} 107^{\circ} 50^{\prime} 59^{\prime \prime} \mathrm{E}\right)$ is the southern part of the large Tam Giang-Cau Hai lagoon system, located on the central coast of Vietnam (Fig. 1). It has an area of approximately 11200 ha. Besides precipitation, there are three main sources of water flows joining into the lagoon: freshwater from Dai Giang and Truoi Rivers in the west of the lagoon, brackish water from the connected Thuy Tu lagoon in the north and saline water from the sea through the Tu Hien inlet in the east. The shallowest areas close to the lagoon edge are used for aquaculture practices (Disperati \& Virdis 2015). The 
area close to the river mouths and the adjacent lagoon are almost completely covered by shrimp farms, whereas the area close to the inlet contains some fish cages (small scale). In general, the strongest aquaculture activity is in the north-western region of the lagoon. Therefore, this region is considered to be a main source of nutrient enrichment for the Cau Hai lagoon (Nguyen \& Yabe 2014, Disperati \& Virdis 2015).

The benthic macrophyte communities in the Cau Hai lagoon are largely dominated by both freshwater macrophytes (Najas indica, Vallisneria spiralis L. and Myriophyllum spicatum L.) and seagrass species (Zostera japonica Asch. \& Graebn., Halophila beccarii, Halophila ovalis, Halodule pinifolia (Miki) Hartog, Halodule uninervis and Ruppia brevipedunculata ShuoYu \& Hartog) (Phan et al. 2018). N. indica and $H$. beccarii are the most dominant species (Phan et al. 2018). During the past decades, the area covered with macrophytes has declined by more than $50 \%$ compared to that in 1990-2000 (Cao et al. 2012). Changes in environmental variables such as salinity, water depth and nutrient availability related to natural and anthropogenic disturbances, may have caused negative effects on macrophyte growth within the lagoon (Thanh et al. 2004, Le 2012, Phan et al. 2018).

\section{Sampling and measurements}

Samples of water, sediment and plants were collected simultaneously at 25 sites (located with Garmin GPS MAP ${ }^{\circledR}$ 78) in Cau Hai lagoon in March, May, July and September 2015 (Fig. 1). Water and sediment were sampled during all four events ( $\mathrm{n}=100$ for water and sediment samples; $\mathrm{n}=50$ for chlorophyll a (Chl-a) which was only measured in the July and September), and macrophytes of the four focus species were collected when present $(\mathrm{n}=23$ for $N$. indica; $\mathrm{n}=28$ for $H$. beccarii; $\mathrm{n}=18$ for $H$. univervis; $\mathrm{n}=8$ for $H$. ovalis). Samples of water, sediment and macrophytes were taken together in four events and formed a gradient of environmental and foliar variables to interpreter correlation among foliar nutrients and environmental variables. All glassware and containers were cleaned with a $5 \% \mathrm{H}_{2} \mathrm{SO}_{4}$ solution and distilled water prior to use. All samples were placed in ice boxes after collection and transported to the laboratory. The details of sampling and measurements are described as follows.

Water. During each sampling event, in-situ measurements were done about $30 \mathrm{~cm}$ below the water surface for water temperature, $\mathrm{pH}$, dissolved oxygen, turbidity and salinity, using a water quality monitoring unit with specific sensors (HORIBA U-5000, Horiba, Japan). Water depth was measured with a depth sounder (Hondex PS-7, Honda
Electronics, Japan). Surface water samples were collected with a Van Dorn sampler at $50 \mathrm{~cm}$ below the surface. The water samples were transferred into glass bottles and transported to the lab in an icebox. Samples for Chl-a analysis were obtained by filtration on glass fibre filters (Whatman $\mathrm{GF} / \mathrm{F}$ ) and were stored in the dark at $-20^{\circ} \mathrm{C}$ until analyses. Unfiltered water samples were stored in glass bottles and frozen until they were submitted to a digestion procedure for total $\mathrm{N}(\mathrm{TN})$ and total $\mathrm{P}(\mathrm{TP})$ analyses. Filtered samples were stored in glass bottles and frozen until they were analyzed for nitrate + nitrite $\left(\mathrm{NO}_{\mathrm{X}}\right)$ and ammonium $\left(\mathrm{NH}_{4}^{+}\right)$spectrophotometrically. All nutrient measurements followed standard protocols (APHA 1998). The dissolved inorganic nitrogen (DIN) was calculated by summation of $\mathrm{NO}_{\mathrm{X}}-\mathrm{N}$ and $\mathrm{NH}_{4}-\mathrm{N}$. Trophic state indices (TSI) of the water were calculated using equations described by Carlson (1977), Kratzer \& Brezonik (1981) for Chl-a, TN and TP, respectively.

Sediment. At each site three replicate sediment cores were taken to a depth of $10 \mathrm{~cm}$, using a sediment core sampler $(4.5 \mathrm{~cm}$ diameter). The fresh sediments were stored in aluminium foil and transported refrigerated to the laboratory. Extractable $\mathrm{N}\left(\mathrm{NO}_{\mathrm{x}}{ }^{-}\right.$and $\left.\mathrm{NH}_{4}^{+}\right)$and dissolved inorganic phosphorus (DIP) were determined by extracting fresh sediment with $2 \mathrm{M} \mathrm{KCl}$ or $0.5 \mathrm{M} \mathrm{NaHCO}_{3}$, respectively (Estefan et al. 2014). Concentrations of $\mathrm{NO}_{\mathrm{x}}^{-}, \mathrm{NH}_{4}^{+}$and 
DIP were measured spectrophotometrically. Fresh sediment samples were dried at $50^{\circ} \mathrm{C}$ for $48 \mathrm{~h}$, ground and analysed for TN using an elemental analyser coupled to an isotope ratio mass spectrometer (EA-IRMS) as described below. TP was analysed using a modification of the combustion $\left(500^{\circ} \mathrm{C}\right.$ for 2 hours) and hot $1 \mathrm{M} \mathrm{HCl}$ extraction procedure of Andersen (1976) according to Johengen (1997). Subsequently, phosphate was measured spectrophotometrically using a molybdate/ascorbic acid procedure (Murphy \& Riley 1962) with an automatic segmented flow nutrient analyser (QuAAtro, Seal Analytical).

Macrophytes. Four focus species (Najas indica, Halophila beccarii, Halodule uninervis and Halophila ovalis) were collected at each site when present. The four macrophytes showed a distinctive spatial distribution in the Cau Hai lagoon (Fig. 1). Green leaves were scraped to remove epiphytes and then rinsed again using distilled water. Once dried $\left(50^{\circ} \mathrm{C}\right.$ for $48 \mathrm{~h}$ in the oven), leaf samples were ground and analysed for $\mathrm{C}, \mathrm{N}, \delta^{13} \mathrm{C}$ and $\delta^{15} \mathrm{~N}$ values using an elemental analyser (Flash1120 series EA, Thermo) coupled to an isotope ratio mass spectrometer (DeltaV, Thermo). Analyses were calibrated against reference materials: IAEACH6 $\left(\mathrm{C}_{12} \mathrm{H}_{22} \mathrm{O}_{11}\right)$ and IAEA-N2 $\left.\left(\mathrm{NH}_{4}\right)_{2} \mathrm{SO}_{4}\right)$ for $\mathrm{C}$ and $\mathrm{N}$ respectively. Samples' isotopic ratios $(\mathrm{R})$ are reported in the standard delta notation $(\delta)$ of the heavy to the light isotope $\left({ }^{13} \mathrm{C} /{ }^{12} \mathrm{C}\right.$ or ${ }^{15} \mathrm{~N} /{ }^{14} \mathrm{~N}$ in either sample or standard) as follows: $\delta(\%)=\left[\left(\mathrm{R}_{\text {Sample }} / \mathrm{R}_{\text {Standard }}\right)-1\right] \times 1000$ (West et al. 2006). TP was determined as described above for sediment samples. C:N:P elemental ratios of studied macrophytes were compared with the benthic macrophyte Redfield Ratio (SRR) of 550:30:1 (Atkinson \& Smith 1983) to evaluate potential growth limiting factors.

\section{Data analysis}

One-way ANOVA and Tukey's post hoc test were used to examine which species were different from each other. Linear regressions were used - per species - to determine the (correlative) influence of water and sediment parameters on foliar nutrients concentrations or isotopic ratios. The effects of environmental variables (explanatory variables) on foliar nutrients of macrophytes (response variables) were visualised with redundancy analysis (RDA) using the vegan package in $\mathrm{R}$ (Oksanen et al. 2013). Multicollinear variables were discarded using the Variance Inflation Factor $(\mathrm{VIF}<4)$, if not already excluded by step-wise selection (Oksanen et al. 2013). For three of the studied plant species, datasets were large enough to calculate a RDA with foliar nutrients and isotopes as well as environmental variables; however, for $H$. ovalis the dataset was too limited. This had to be done per species because of interspecific differences in foliar nutrient and isotopes. To meet test assumptions of parametric statistics, data were log-transformed if needed. All analyses were carried out with $\mathrm{R}$ version 3.4 .0 on R-Studio (Logan 2010, R Core Team 2017).

The geostatistical kriging technique was used to interpolate the spatial distribution of key water variables in the lagoon that have significant spatial variation (saliity, depth and DIN in the water). Kriging assumes that the distance or direction between sample points reflects a spatial correla- tion that can be used to predict unknown values for any geographic point data (Goovaerts 1997, Daya \& Bejari 2015). The method with smaller prediction errors will be selected for the spatial interpolation. The model type, nugget, sill and range were modified to fit each of the variogram models by using ISATIS Software (Geovariances 2016).

\section{RES U LT S}

\section{Distribution of key environmental factors and macrophytes}

Water and sediment variables showed strong variation in space or time (Table 1). There was a clear west-east gradient in salinity (Fig. 2A; Fig. 3A), as well as a north-south gradient in water depth (Fig. 2B). There were also spatial gradients in DIN concentrations in the water with higher values in the western part of the lagoon (Fig. 2C; Fig. 3C), whereas, the $\mathrm{P}$ concentrations did not show spatial variation (Table 1; Fig. 3D). Additionally, salinity, concentrations of $\mathrm{N}$ and $\mathrm{P}$ in the water and sediment varied in time (Table 1).

The four macrophytes showed a distinctive spatial distribution in the Cau Hai lagoon (Fig. 1, 3). N. indica and $H$. beccarii occurred in the western and central parts of the lagoon with lower salinity and higher DIN concentrations (Fig. 3A, C). Whereas, $H$. uninervis occurred in the central and eastern part and $H$. ovalis occurred only at two sites in the eastern part with higher salinity and lower DIN concentrations) (Fig. 3A, C). Furthermore, H. uninervis and H. ovalis distributed in the narrow range of salinity, water depth, DIN and DIP concentrations (Fig. 3).

\section{Interspecific variation in macrophyte foliar $C, N, P, \delta^{13} C$ and $\delta^{15} N$}

There were significant differences in foliar $\mathrm{C}, \mathrm{N}$ and $\mathrm{C}: \mathrm{N}$ among the four studied species (averaged over time and space), but not in foliar P, C:P or N:P (Fig. 4). H. beccarii had a relatively high foliar $\mathrm{N}(3.1 \pm 0.1 \%)$ and a low foliar $\mathrm{C}(32.0 \pm 0.8 \%)$ concentration and therefore a lower foliar C:N $(12.7 \pm 0.5)$ than the three other species (Fig. 4D), whereas $H$. ovalis had the lowest foliar $\mathrm{N}$ concentration $(2.3 \pm 0.1 \%)$ (Fig. 4B).

The macrophyte species clearly differed in foliar $\delta^{13} \mathrm{C}$, with most negative values for $N$. indica $(-18.4 \pm 0.3 \%$ ) and $H$. beccarii $(-17.3 \pm 0.5 \%)$ and least negative for $H$. ovalis $(-10.7 \pm 0.5 \%$ ) (Fig. $4 \mathrm{G})$. Foliar $\delta^{15} \mathrm{~N}$ of $H$. uninervis $(1.3 \pm 0.5 \%$ o was significantly lower than that of the three other species (Fig. 4H).

\section{Correlations among macrophyte foliar nutrients and environmental variables}

The foliar $\mathrm{N}$ of $\mathrm{N}$. indica and foliar C: $\mathrm{N}$ of $H$. beccarii were significant correlated to DIN concentrations in the water (Fig. 5A, B; 6A, C). Correlations of foliar P and C:P and DIP concentrations in the sediment were observed in N. indica (Fig. 5A, 6B). For H. uninervis, foliar P and C:P were correlated to water depth (Fig. 5C, 6D).

Foliar $\delta^{13} \mathrm{C}$ values of $H$. beccarii and $H$. uninervis were positively correlated to salinity (Fig. 5B, C; 6E). Noteworthy, the difference in foliar $\delta^{13} \mathrm{C}$ among studied species did not depend on salinity; i.e., the interaction between species and salinity was not significant $(F=1.0$ and $p=0.39)$. A significant 
Table 1. Summary statistics for water and sediment parameters (means \pm S.E) and one-way ANOVA results for effects of sampling time and sampling site. The number of observations for each quantity=100; for Chl-a: $\mathrm{n}=50$. The significant statistics are shown in bold. Levels of significance are as follows: ${ }^{*} p<0.05 ;{ }^{*} p<0.01 ; * * p<0.001$.

\begin{tabular}{|c|c|c|c|c|c|}
\hline \multirow{2}{*}{ Parameter } & \multirow{2}{*}{ Min } & \multirow{2}{*}{$\operatorname{Max}$} & \multirow{2}{*}{ Mean \pm S.E } & \multicolumn{2}{|c|}{ ANOVA (F ratio) } \\
\hline & & & & Time & Site \\
\hline \multicolumn{6}{|l|}{ Water quality parameters } \\
\hline Temperature $\left({ }^{\circ} \mathrm{C}\right)$ & 26.2 & 35.2 & $31.38 \pm 0.20$ & $170.99 * * *$ & 0.25 \\
\hline $\mathrm{pH}$ & 5.4 & 11.6 & $8.52 \pm 0.10$ & $9.35 * * *$ & 0.96 \\
\hline $\mathrm{DO}(\mathrm{mg} / \mathrm{L})$ & 3.8 & 11.2 & $7.22 \pm 0.15$ & $18.46 * * *$ & 0.46 \\
\hline Salinity $(\% 0)$ & 0.2 & 29.9 & $13.65 \pm 0.61$ & $15.96 * * *$ & $4.64 * * *$ \\
\hline Turbidity (NTU) & 0.0 & 50.8 & $4.93 \pm 0.68$ & 41.38 & 0.89 \\
\hline Water depth (m) & 0.5 & 2.4 & $1.51 \pm 0.42$ & 0.50 & $26.46 * * *$ \\
\hline $\mathrm{NO}-\mathrm{N}(\mu \mathrm{g} / \mathrm{L})$ & 7.1 & 54.9 & $18.97 \pm 0.81$ & $2.82 *$ & 1.18 \\
\hline $\mathrm{NH}_{4}^{\mathrm{x}}-\mathrm{N}(\mu \mathrm{g} / \mathrm{L})$ & 17.4 & 241.2 & $58.48 \pm 3.81$ & $3.06 *$ & 0.82 \\
\hline $\mathrm{DIN}(\mu \mathrm{g} / \mathrm{L})$ & 31.4 & 269.7 & $77.45 \pm 4.20$ & 1.52 & $3.83 *$ \\
\hline $\mathrm{TN}(\mu \mathrm{g} / \mathrm{L})$ & 114.2 & 770.6 & $403.77 \pm 12.91$ & 0.36 & $9.67 * *$ \\
\hline $\mathrm{TP}(\mu \mathrm{g} / \mathrm{L}$ & 7.0 & 132.8 & $29.07 \pm 2.03$ & $7.89 * *$ & 0.95 \\
\hline TN:TP (Molar base) & 8.6 & 79.5 & $39.51 \pm 1.79$ & 2.65 & 1.18 \\
\hline Chl-a $(\mu \mathrm{g} / \mathrm{L})$ & 0.4 & 105.9 & $6.3 \pm 2.1$ & 1.90 & $3.39 *$ \\
\hline TSI & 31.3 & 79.0 & $44.1 \pm 0.6$ & 1.04 & $4.96 * *$ \\
\hline \multicolumn{6}{|c|}{ Sediment quality parameters } \\
\hline $\mathrm{NO}-\mathrm{N}(\mathrm{mg} / \mathrm{Kg})$ & 0.3 & 19.2 & $1.96 \pm 0.22$ & $14.57 * * *$ & 1.22 \\
\hline $\mathrm{NH}_{4}^{\mathrm{x}}-\mathrm{N}(\mathrm{mg} / \mathrm{Kg})$ & 4.3 & 30.7 & $15.46 \pm 0.53$ & 1.51 & $3.85 *$ \\
\hline $\mathrm{DIN}(\mathrm{mg} / \mathrm{Kg})$ & 4.7 & 32.5 & $17.03 \pm 0.53$ & 0.56 & $3.39 *$ \\
\hline $\mathrm{PO}_{4}-\mathrm{P}(\mathrm{mg} / \mathrm{Kg})$ & 1.1 & 17.0 & $4.07 \pm 0.26$ & $2.40 *$ & 0.87 \\
\hline DIN:DIP (Molar base) & 1.2 & 33.2 & $12.69 \pm 0.75$ & $1.78^{*}$ & 1.74 \\
\hline $\mathrm{TN}(\% \mathrm{dw})$ & 0.5 & 2.9 & $1.53 \pm 0.05$ & $1.87 *$ & 0.99 \\
\hline $\mathrm{TP}(\mathrm{g} / \mathrm{Kg})$ & 0.05 & 0.5 & $0.20 \pm 0.01$ & $6.16 *$ & 0.88 \\
\hline TN:TP (Molar base) & 7.4 & 63.1 & $23.02 \pm 1.13$ & 1.21 & 0.65 \\
\hline
\end{tabular}

correlation between foliar $\delta^{15} \mathrm{~N}$ and environmental variables was only found for $N$. indica, foliar $\delta^{15} \mathrm{~N}$ was negatively correlated to salinity and positively correlated to DIN in water (Fig. 5A, 6H).

\section{DISCUSSION}

\section{Variation in foliar $\mathbf{C}, \mathbf{N}$ and $\mathbf{P}$ and their ratios}

Foliar $\mathrm{C}$ and $\mathrm{N}$ concentrations differed among species, whereas $\mathrm{P}$ did not. Foliar $\mathrm{C}$ and $\mathrm{C}: \mathrm{N}$ were relatively low in $H$. beccarii. This species might have less structural carbon (as indicated by depleted C:N and C:P ratios) than the other three species, as was also found for Cymodocea nodosa (Ucria) Asch. near the Balearic Islands (Fourqurean et al. 2007). Foliar $\mathrm{N}$ was low in H. ovalis, but this difference was likely a consequence of the limited spatial occurrence in the far eastern part of the lagoon where $\mathrm{N}$ concentrations in the water and sediment were relatively low, rather than an inherent difference between species. At two other sites in Australia and Fiji where $H$. ovalis co-occurred with one of the other species (H. uninervis), H. ovalis had a higher $\mathrm{N}$ concentration (Yamamuro et al. 2003), which supports that the lower $\mathrm{N}$ concentration of $H$. ovalis in the Cau Hai lagoon was likely not due to inherent interspecific differences and/ or insignificant fluctuation of DIN concentration in its distributed areas (Fig. 3C). Noteworthy, numbers of replication was too low for statistical comparisons among species that occurred at the same sites.

Variation in foliar $\mathrm{N}$ and $\mathrm{C}: \mathrm{N}$ was associated with variation in DIN concentration in the water, although only observed for $N$. indica and $H$. beccarii. This suggests that DIN concentration in the water column was an important source of $\mathrm{N}$ for these macrophyte species, particularly in the north western part of the lagoon. In this region, a relatively high DIN concentration in the water compared to plant demand might have led to excess uptake of DIN or 'luxury consumption' by the macrophytes, as observed in other studies (cf. Gordon et al. 1981, Stapel \& Hemminga 1997, Ferdie \& Fourqurean 2004, Apostolaki et al. 2011, Vizzini et al. 2004, Walton et al. 2016). Similarly, Zostera
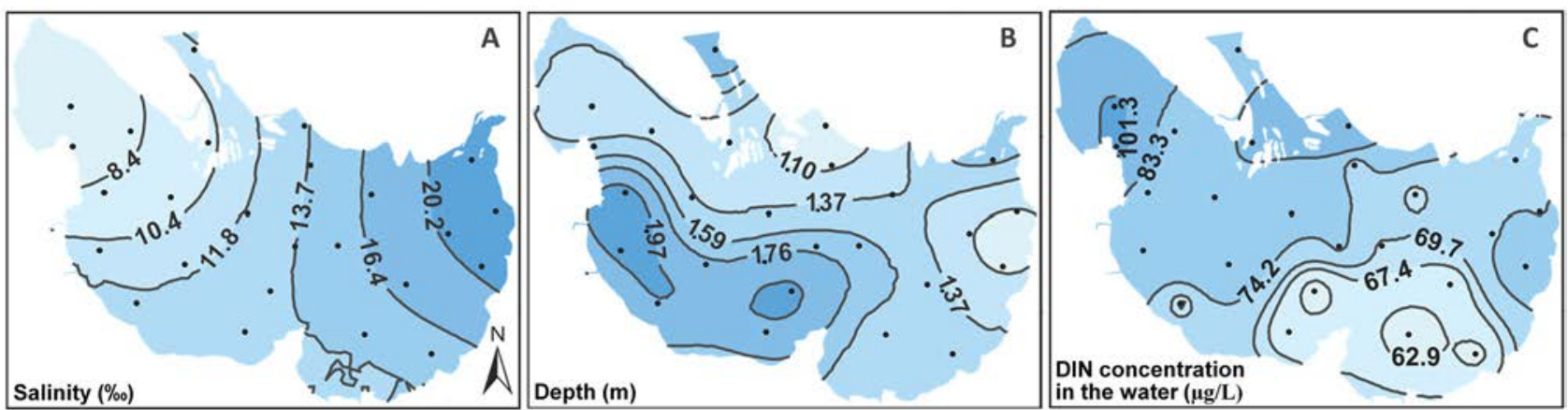

Figure 2 Spatial variation in mean salinity, depth, DIN concentration in the water collected between March and September 2015 in the Cau Hai lagoon. Black dots indicate locations of the 25 permanent sampling sites used for spatial interpolations. The darkness of the shading increases with the value of variables 

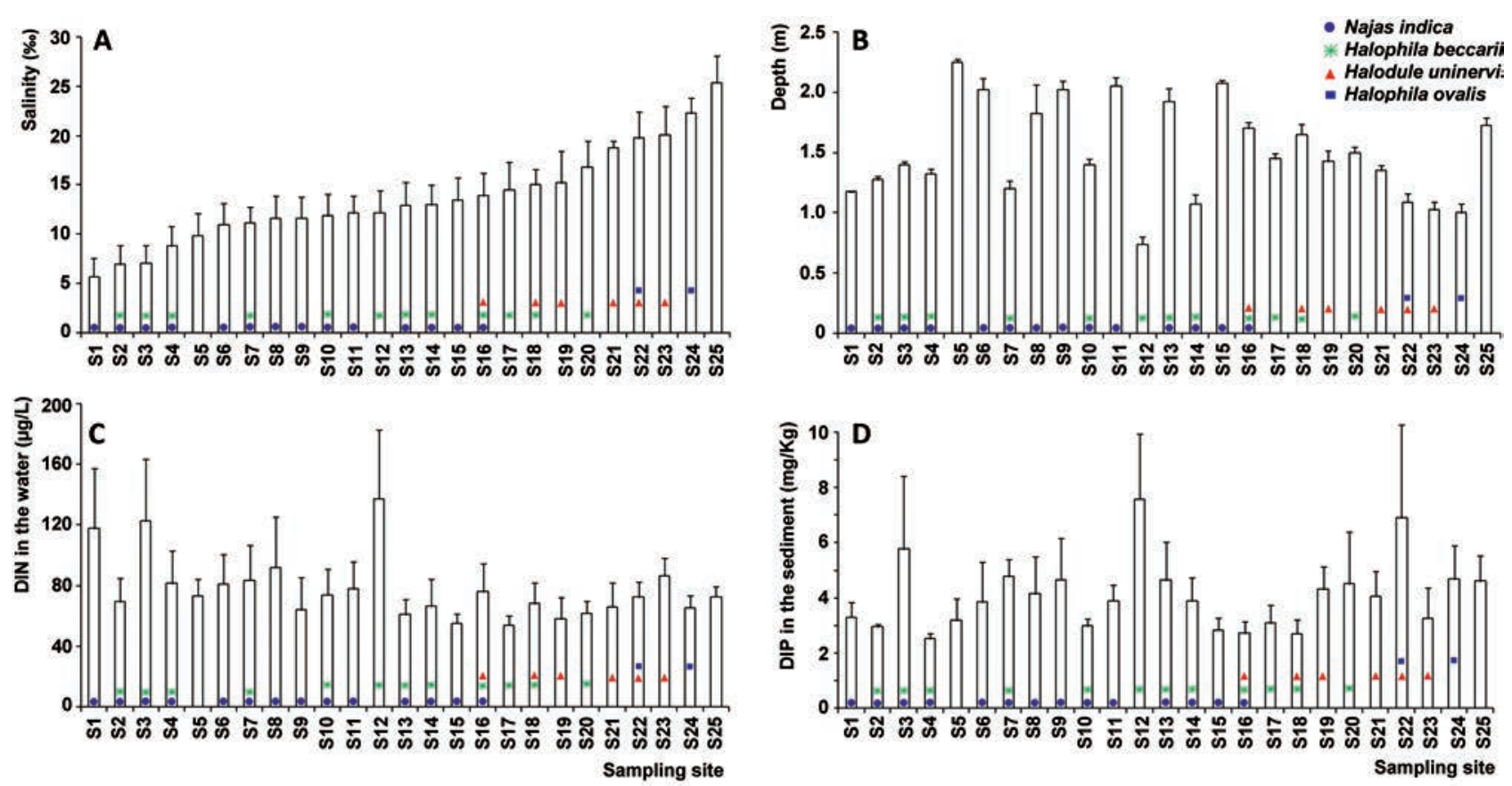

Figure 3 Distribution of key environmental variables and four macrophyte species at 25 sampling sites in Cau Hai lagoon. Bars charts indicate environmental variables: salinity (A), depth (B), DIN concentration in the water (C) and DIP concentration in the sediment (D). Error bars are the standard error of the means of environmental variables. Dots inside the bar charts indicate the presence of macrophyte species: Najas indica (Willd.) Cham. ( $\mathrm{n}=23)$; Halophila beccarii Aschers. $(\mathrm{n}=28)$, Halodule uninervis (Forssk.) Boiss. $(\mathrm{n}=18)$ and Halophila ovalis $(\mathrm{R}$. Br.) Hook. $\mathrm{f}$. $(\mathrm{n}=8)$

marina L. in Atlantic Canada showed an increasing foliar $\mathrm{N}$ concentration with $\mathrm{N}$ enrichment although its biomass declined due to shading (Schmidt et al. 2018). Variation in foliar P and C:P could not be ascribed to differences in P in the water, but for $N$. indica foliar P was positively correlated to variation in DIP in the sediment. This indicates that for this species P-acquisition by the roots from the sediment may be an important factor as observed for Najas marina in Myall Lake, Australia (Shilla et al. 2006). Foliar P of $H$. uninervis was not correlated to $\mathrm{P}$ in water or sediment, but it increased with increasing water depth. There is no good explanation for these correlations, at this point.

The average concentrations of $\mathrm{C}, \mathrm{N}$ and $\mathrm{P}$ and their ratios in the macrophytes of the Cau Hai lagoon indicate that these plants likely experienced relatively high $\mathrm{N}$ and $\mathrm{P}$ availability. The average C:N (15) and C:P ratios (464) of all species were clearly below the Redfield Ratio for benthic macrophytes (C:N $\approx 18, \mathrm{C}: \mathrm{P} \approx 550$ ) (Atkinson \& Smith 1983, Duarte 1990, Johnson et al. 2006). Foliar N and P concentrations in this study $(2.3-3.1 \%$ for N, 0.19-0.21\% for P) were in the range of the data reported in other coastal areas (1.6-3.1 \% for $\mathrm{N}$ and $0.14-0.44 \%$ for P; Yamamuro et al. 2003, Walton et al. 2016). Plants growing in excess nutrient conditions reflect this in high $\mathrm{N}$ and $\mathrm{P}$ concentrations compared to C (Atkinson \& Smith 1983, Duarte 1990, Johnson et al. 2006). A moderate to high nutrient availability as indicated by the foliar nutrients in the plants agreed with trophic state indices in Cau Hai lagoon. Hence, it appears that another factor than $\mathrm{P}$ or $\mathrm{N}$ inhibited C-fixation and/ or carbon storage of macrophytes (Burkholder et al. 2007).

\section{Variation in foliar $\delta^{13} \mathrm{C}$ and $\delta^{15} \mathrm{~N}$}

On average, foliar $\delta^{13} \mathrm{C}$ values differed strongly among the four macrophyte species of this study reflecting interspecific variation in bicarbonate acquisition mechanisms (Invers et al. 1999, Schwarz et al. 2000, Uku et al. 2005, Borum et al. 2016). The difference was also partly due to variation in the spatial distribution and salinity of the macrophyte species' habitats, although the difference among studied species did not depend on salinity (the species $\times$ salinity interaction was not significant). The observed interspecific trend in $\delta^{13} \mathrm{C}(H$. ovalis $>H$. uninervis $>H$. beccarii $>N$. indica $)$ was consistent with the limited available information about $\delta^{13} \mathrm{C}$ values of macrophytes from previous studies (Wetzel 1969 in Keeley \& Sandquist 1992). Averaged per species, we observed the most negative values for N. indica (-18\%0) which were in the range of previously observed freshwater macrophytes (-11 to $-50 \%$; Wetzel 1969 in Keeley \& Sandquist 1992, Chappuis et al. 2017). Moreover, Wetzel (1969) observed that the foliar $\delta^{13} \mathrm{C}$ value of the closely related species Najas flexilis (Willd.) Rostk. \& Schmidt was quite low $\left(-22 \%\right.$ ) because it did not take up $\mathrm{HCO}_{3}^{-}$(Wetzel 1969 in Keeley \& Sandquist 1992). This may also count for $N$. indica in the Cau Hai lagoon given its low foliar $\delta^{13} \mathrm{C}$ value. Also, the relatively low $\delta^{13} \mathrm{C}$ value of $H$. beccarii $(17 \%$ ) in comparison to the other Halophila species is consistent with previous studies (McMillan et al. 1980 in Hemminga \& Mateo 1996). Highest $\delta^{13} \mathrm{C}$ values (-10.7\%0) were observed in $H$. ovalis which occurred at the shallowest depth (Fig. 3B) and highest salinity suggesting that photosynthesis of this species may depend more on $\mathrm{HCO}_{3}{ }^{-}$as a carbon source (Borum et al. 2016) than the three other species. Foliar $\delta^{13} \mathrm{C}$ of $H$. beccarii and $H$. uninervis in the Cau Hai lagoon increased with salinity, as was previously observed in other coastal waters (Fry 2002, Hitchcock et al. 2017). Generally, $\delta^{13} \mathrm{C}$ in seagrasses ranges from $-24 \%$ to $-3 \%$ (Hemminga \& Mateo 1996, Anderson \& Fourqurean 2003), where the least negative values in marine primary producers indicate 

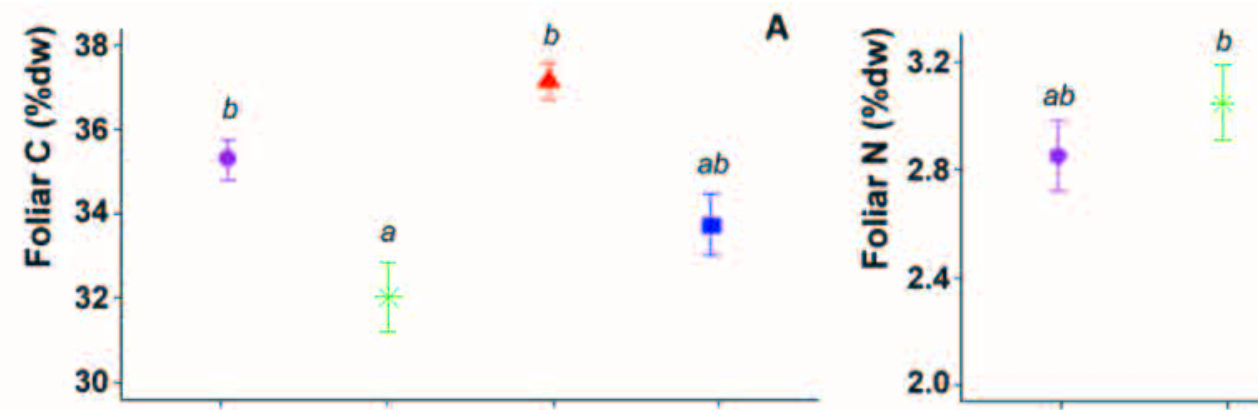

B
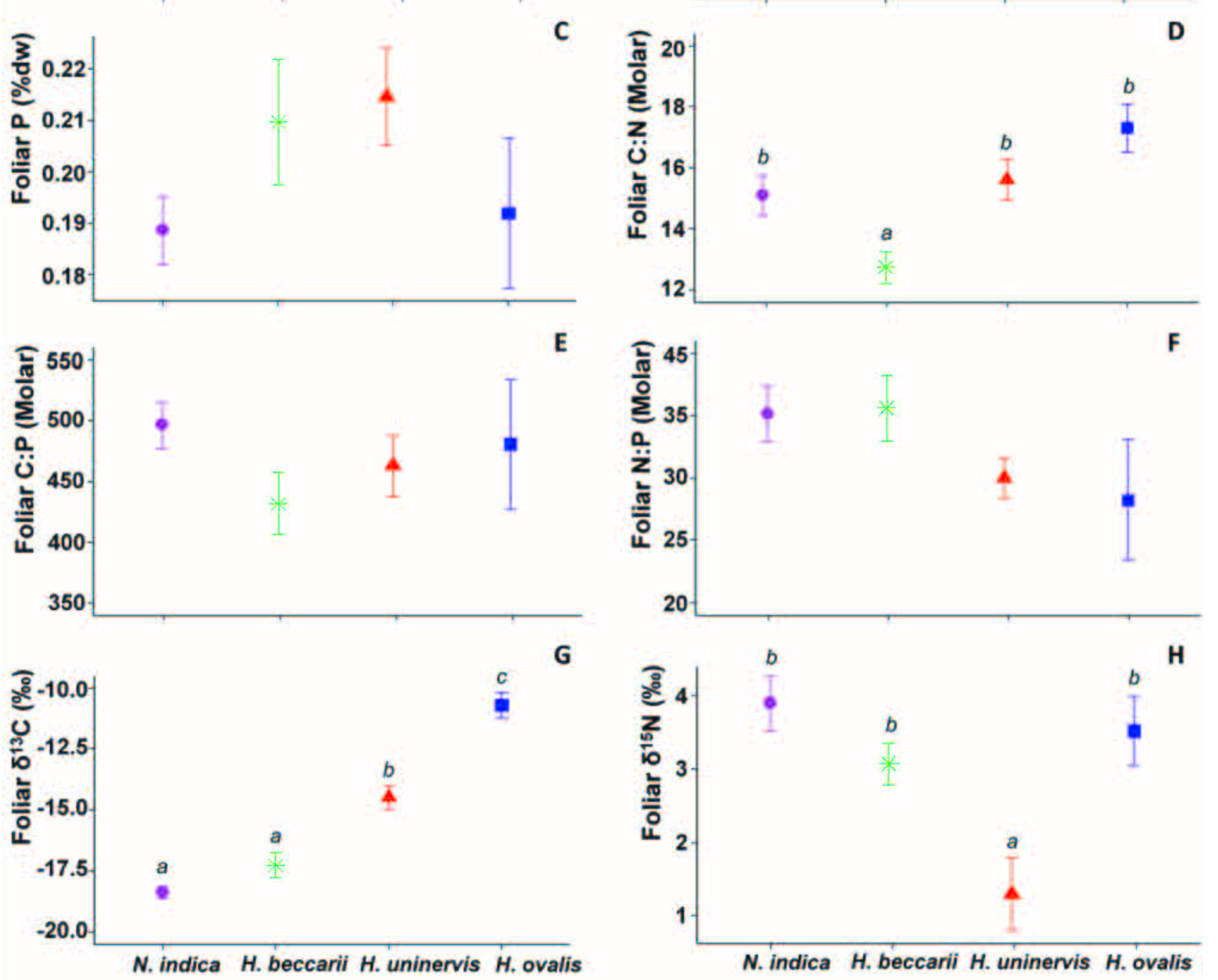

Figure 4 Mean foliar carbon, C (A), nitrogen, N (B), phosphorus, P (C) concentrations, ratios of C:N (D), C:P (E) and N:P (F) as well as stable isotopes $\delta^{13} \mathrm{C}(\mathrm{G})$ and $\delta^{15} \mathrm{~N}(\mathrm{H})$ of four macrophyte species collected in 2015 in the Cau Hai lagoon. Error bars are the standard error of the means. Significant differences are indicated by different letters at $\mathrm{p}<0.05$ (Tukey's test after Anova Type II, taking into account the repetitive measurements). Freshwater species: Najas indica (Willd.) Cham. $(\bullet$ purple, $\mathrm{n}=23)$; Seagrass species: Halophila beccarii Aschers. $(*$, green, $\mathrm{n}=28)$, Halodule uninervis (Forssk.) Boiss. $(\boldsymbol{\Lambda}$, red, $\mathrm{n}=18)$ and Halophila ovalis (R. Br.) Hook. f. ( $\mathbf{\bullet}$, blue, $\mathrm{n}=8)$

a relatively high assimilation of $\mathrm{HCO}_{3}^{-}$instead of $\mathrm{CO}_{2}$ (Hemminga \& Mateo 1996) to adapt to marine life (Beer et al. 2002). These foliar $\delta^{13} \mathrm{C}$ values were much lower than those observed in the saline habitats such as Shark Bay, Australia $\left(\delta^{13} \mathrm{C}=-13.2 \%\right.$ in Halodule uninervis, salinity $>42 \%$, Fraser et al. 2012) and Bermuda $\left(\delta^{13} \mathrm{C}=-9.6 \%\right.$ in Halodule sp., salinity $>36 \%$, Fourqurean et al. 2015). The positive correlation between foliar $\delta^{13} \mathrm{C}$ and salinity may also reflect that the isotopic signature of dissolved inorganic $\mathrm{C}$ varies with salinity, from close to $0 \%$ in ocean waters to $-10 \% 0$ to $-15 \%$ in freshwaters (Mook 2000). Indeed, according to Henry's law, dissolution of $\mathrm{CO}_{2}$ in water is a function of temperature and salinity. Under the high $\mathrm{pH}$ conditions in the brackish water of the Cau Hai lagoon (8.5 \pm 0.1$)$, DIC may be comprised for more than $80 \%$ of $\mathrm{HCO}_{3}^{-}$(Michener \& Lajtha 2007, Schmidt et al. 2012). Macrophytes species vary in their ability to use $\mathrm{HCO}_{3}^{-}$. In Cau Hai lagoon, $H$. beccarii and $H$. uninervis appeared to acquire relatively high amounts of $\mathrm{C}$ from bicarbonate.

$H$. uninervis had a consistently lower foliar $\delta^{15} \mathrm{~N}$ value compared to the other three species in the Cau Hai lagoon, which supported previous observations for this species 

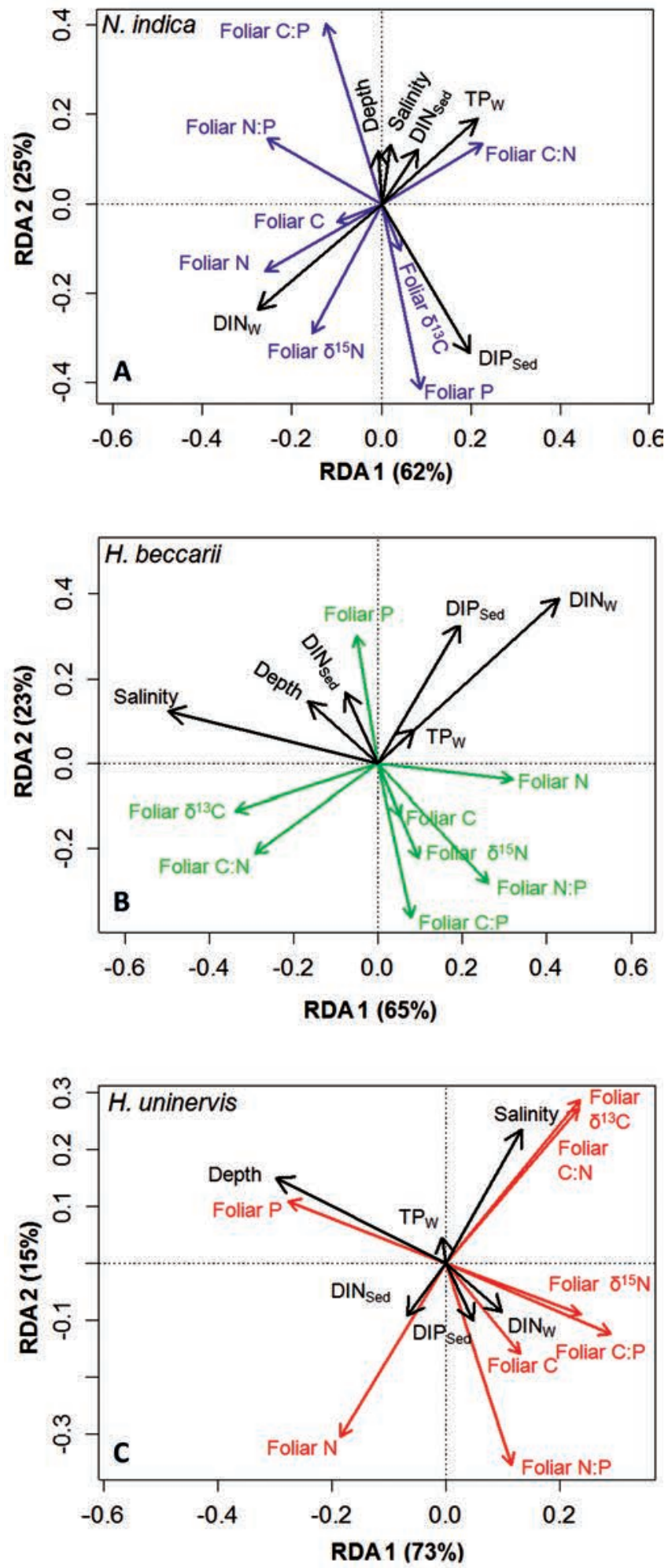

Figure 5 Biplots of the first two axes of the redundancy analysis showing the association of macrophyte occurrence $\left(R^{2}=0.38\right.$, $\mathrm{p}=0.02)$, foliar nutrients and environmental variables: Najas indica (Willd.) Cham. ( $\left.\mathrm{R}^{2}=0.52, \mathrm{p}=0.04\right), H$. beccarii $\left(\mathrm{R}^{2}=0.39, \mathrm{p}=0.011\right)$, Halodule uninervis (Forssk.) Boiss. $\left(\mathrm{R}^{2}=0.56, \mathrm{p}=0.012\right)$. Abbreviation: DIN $_{w}$, DIN $_{\mathrm{Sed}}$ : DIN concentrations in the water and sediment, respectively; $\mathrm{TP}_{\mathrm{W}}$ : TP concentration in the water; $\mathrm{DIP}_{\mathrm{Sed}}$ : DIP concentration in the sediment

in other regions (Yamamuro et al. 2003, Frase et al. 2012, Walton et al. 2016). This indicates that this species either differed from the other species in the proportions of $\mathrm{N}$ that it acquires from the various $\mathrm{N}$ sources (e.g. nitrate and ammonium in water or sediment), or that the relationship between the $\mathrm{N}$ demand and $\mathrm{N}$ availability was different for this species (Peipoch et al. 2014, Fourqurean et al. 2015, Walton et al. 2016). Although foliar $\delta^{15} \mathrm{~N}$ of $H$. uninervis was correlated differently to the measured environmental variables than that of $N$. indica (cf. temperature, $\mathrm{pH}$; Table 2), we could not identify a different source of $\mathrm{N}$ for $\mathrm{H}$. uninervis. With a lower demand for nitrogen, plants discriminate more against the heavier isotope, as was described for Halodule uninervis in Al Khor bay (Qatar) (Walton et al. 2016) and Moreton Bay or in an experiment in Green Island (Australia) with an excess supply of nitrogen (Udy \& Den nison 1997). Generally, foliar $\delta^{15} \mathrm{~N}$ values of macrophytes growing in anthropogenically disturbed water are higher than those of macrophytes from undisturbed habitats (Fourqurean et al. 1997, Yamamuro et al. 2003, Lepoint et al. 2008, Herbeck et al. 2014, Hitchcock et al. 2017). In our study, foliar $\delta^{15} \mathrm{~N}$ values were highest in the north-western part of the lagoon as observed in foliar $\delta^{15} \mathrm{~N}$ of $\mathrm{N}$. indica $(3.9 \pm 0.8 \%$ ) , where aquaculture activity is most intensive and where also DIN concentrations are at the highest. Foliar $\delta^{15} \mathrm{~N}$ of macrophytes in the Cau Hai lagoon where high compared to values from undisturbed waters, such as Dravuni (Fiji) and Green Island (Australia) (Yamamuro et al. 2003). This indicates that the Cau Hai lagoon suffers from $\mathrm{N}$ enrichment, at least in the north-western part as illustrated by the spatial patterns of DIN concentrations in the water (Fig. 2C). The lagoon on average would be classified as mesotrophic (ranging 40-50) according trophic state indices (TSI) of Carlson (1977), Kratzer and Brezonik (1981), but locally it could vary from oligotrophic $($ TSI $<40)$ to eutrophic (TSI=50-70) (Table 1$)$.

\section{CONCLUSION}

There was a considerable interspecific variation in foliar nutrient concentrations and isotopic composition in the studied macrophytes in the Cau Hai lagoon. This variation was associated to intrinsic interspecific differences (different $\mathrm{N}$ source of $H$. uninervis), natural variation in habitat conditions among species (salinity, depth), and anthropogenic influences ( $\mathrm{N}$ enrichment). Variations in foliar $\mathrm{N}$ and $\mathrm{P}$ could be explained by the measured variation in environmental conditions only to a limited extent. Variations in foliar $\delta^{13} \mathrm{C}$ and $\delta^{15} \mathrm{~N}$ among species were distinct and were likely related to variation in $\mathrm{C}$ and $\mathrm{N}$ acquisition and in DIN availability. The high nutrient concentrations in the studied macrophytes in Cau Hai lagoon indicates that possibly another factor was limiting growth of these plants such as excess nutrients affecting their nutrient uptake and growth rate (toxicity or inhibited C-fixation) or shading from algae (phytoplankton, macroalgae and epiphyte) (Whalen et al. 2013).

Competing Interests Statement: The authors declare no competing interests.

Author Contributions Statement: D.T.N.Y. and H.O.V. designed the study. D.T.N.Y. collected field samples, analysed water, sediment and macrophyte samples; N.B.D.V., P.C. and T.S. contributed to the chemical analyses. N.T.H 

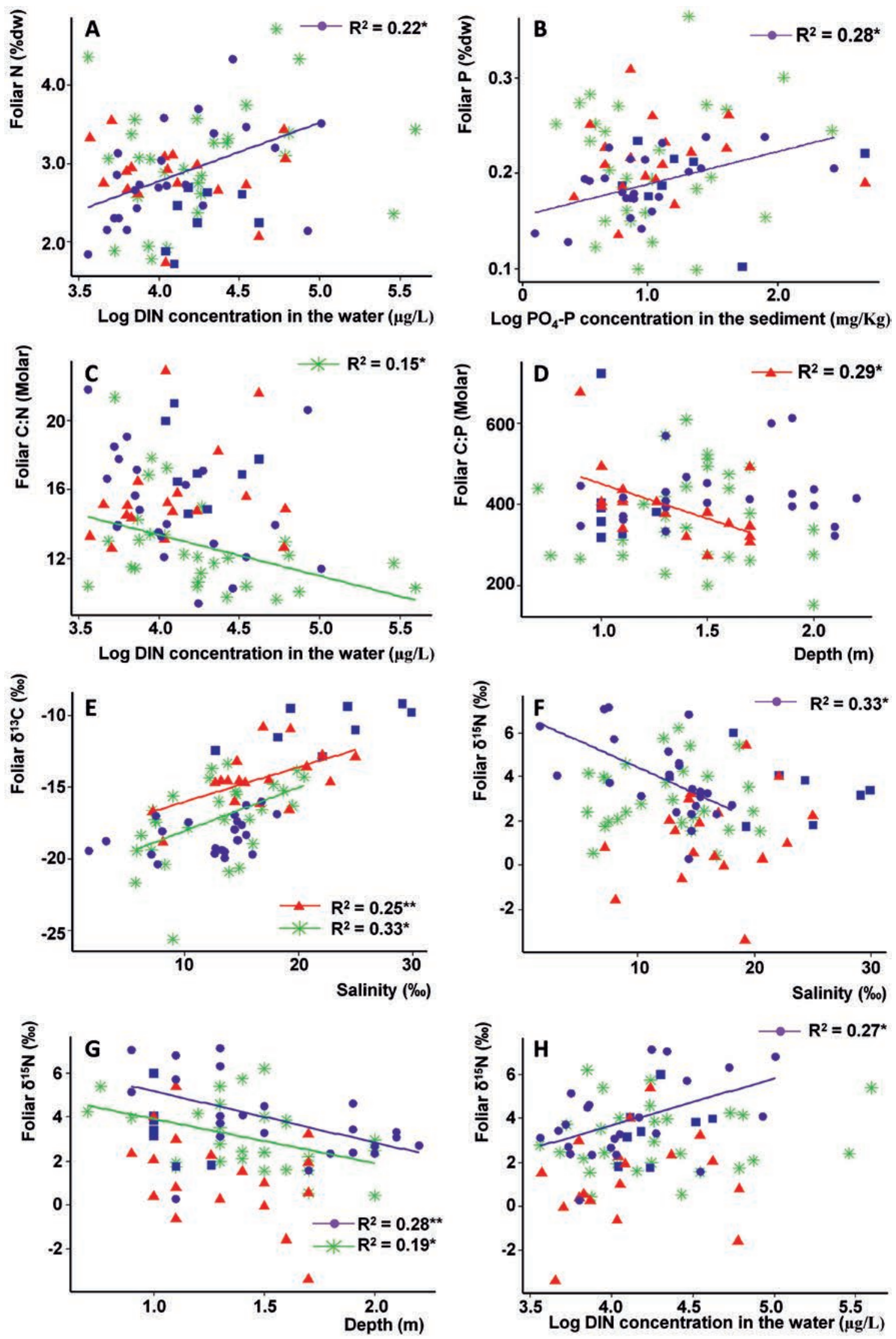

Figure 6 Correlations between foliar nutrients and environmental parameters in Cau Hai lagoon. Only significant regression lines are drawn. Levels of significance are as follows: ${ }^{*} \mathrm{p}<0.05 ;{ }^{*} \mathrm{p}<0.01$. Freshwater species: Najas indica (Willd.) Cham. $(\bullet$, purple, $\mathrm{n}=23)$; Seagrass species: Halophila beccarii Aschers. (*, green, $\mathrm{n}=28)$, Halodule uninervis (Forssk.) Boiss. ( $\boldsymbol{\Delta}$, red, $\mathrm{n}=18)$ and Halophila ovalis (R. Br.) Hook. f. $(\mathbf{\bullet}$, blue, $\mathrm{n}=8)$ 
Nhu Y et al.

Table 2. Pearson correlation coefficients ( $\mathrm{r}$ ) of plant, water and sediment quality parameters. Levels of significance are as follows: ${ }^{*} p<0.05 ;{ }^{*} p<0.01$. N. indica: $\mathrm{n}=23, H$. beccarii: $\mathrm{n}=28$, H. uninervis: $\mathrm{n}=18$, H. ovalis: $\mathrm{n}=8$

\begin{tabular}{|c|c|c|c|c|c|c|c|c|c|c|c|c|c|c|}
\hline \multirow{2}{*}{ Plant parameters } & & \multicolumn{8}{|c|}{ Water parameters } & \multicolumn{5}{|c|}{ Sediment parameters } \\
\hline & & Temp & $\mathrm{pH}$ & Salinity & Depth & DIN & TN & TP & TN:TP & DIN & DIP & TN & TP & TN:TP \\
\hline $\begin{array}{l}\text { Najas indica } \\
\text { Halophila beccarii } \\
\text { Halodule uninervis } \\
\text { Halophila ovalis }\end{array}$ & Foliar C & $\begin{array}{r}.02 \\
.17 \\
-.33 \\
-.11\end{array}$ & $\begin{array}{l}.43^{*} \\
-.09 \\
-.20 \\
.26\end{array}$ & $\begin{array}{l}.38 \\
-.05 \\
-.25 \\
-.21\end{array}$ & $\begin{array}{l}-.25 \\
-.18 \\
-.12 \\
-.37\end{array}$ & $\begin{array}{r}.31 \\
-.18 \\
.37 \\
.63\end{array}$ & $\begin{array}{l}.08 \\
.17 \\
-.29 \\
-.19\end{array}$ & $\begin{array}{r}-.08 \\
.32 \\
-.25 \\
.07\end{array}$ & $\begin{array}{r}.07 \\
-.21 \\
.18 \\
-.13\end{array}$ & $\begin{array}{r}.13 \\
-.14 \\
-.03 \\
.17\end{array}$ & $\begin{array}{l}.12 \\
-.13 \\
-.07 \\
-.01\end{array}$ & $\begin{array}{l}.05 \\
.03 \\
.11 \\
-.81^{*}\end{array}$ & $\begin{array}{r}.24 \\
.26 \\
-.04 \\
-.64\end{array}$ & $\begin{array}{l}.25 \\
-.22 \\
.14 \\
.47\end{array}$ \\
\hline $\begin{array}{l}\text { Najas indica } \\
\text { Halophila beccarii } \\
\text { Halodule uninervis } \\
\text { Halophila ovalis }\end{array}$ & Foliar $\mathbf{N}$ & $\begin{array}{r}.00 \\
-.09 \\
-.34 \\
-.63\end{array}$ & $\begin{array}{l}.11 \\
-.07 \\
-.04 \\
-.02\end{array}$ & $\begin{array}{l}-.22 \\
-.31 \\
-.47 \\
-.15\end{array}$ & $\begin{array}{r}-.12 \\
-.34 \\
.35 \\
-.50\end{array}$ & $\begin{array}{l}.49^{*} \\
.24 \\
-.12 \\
.40\end{array}$ & $\begin{array}{r}-.33 \\
.15 \\
-.20 \\
-.38\end{array}$ & $\begin{array}{l}-.48^{*} \\
.21 \\
-.24 \\
-.14\end{array}$ & $\begin{array}{r}.40 \\
-.04 \\
.17 \\
-.02\end{array}$ & $\begin{array}{r}-.02 \\
-.15 \\
.11 \\
.47\end{array}$ & $\begin{array}{l}.09 \\
.05 \\
.20 \\
.20\end{array}$ & $\begin{array}{c}.05 \\
.02 \\
.40 \\
-.78^{*}\end{array}$ & $\begin{array}{c}-.36 \\
.07 \\
.15 \\
-.71^{*}\end{array}$ & $\begin{array}{r}.30 \\
-.03 \\
-.04 \\
.58\end{array}$ \\
\hline $\begin{array}{l}\text { Najas indica } \\
\text { Halophila beccarii } \\
\text { Halodule uninervis } \\
\text { Halophila ovalis }\end{array}$ & Foliar P & $\begin{array}{l}.28 \\
.14 \\
.03 \\
.18\end{array}$ & $\begin{array}{r}.12 \\
-.10 \\
.39 \\
-.08\end{array}$ & $\begin{array}{r}-.18 \\
.22 \\
-.24 \\
.33\end{array}$ & $\begin{array}{l}-.21 \\
.04 \\
.61^{* *} \\
.07\end{array}$ & $\begin{array}{r}.23 \\
-.06 \\
-.27 \\
-.06\end{array}$ & $\begin{array}{r}.19 \\
.24 \\
-.05 \\
.05\end{array}$ & $\begin{array}{r}-.16 \\
.13 \\
-.19 \\
.09\end{array}$ & $\begin{array}{r}.26 \\
.06 \\
.20 \\
-.08\end{array}$ & $\begin{array}{r}-.15 \\
.03 \\
-.03 \\
.31\end{array}$ & $\begin{array}{l}.5^{* *} \\
.09 \\
.02 \\
-.04\end{array}$ & $\begin{array}{l}-.14 \\
-.42^{*} \\
.47^{*} \\
-.14\end{array}$ & $\begin{array}{r}.10 \\
.04 \\
.25 \\
.27\end{array}$ & $\begin{array}{l}-.06 \\
-.36 \\
-.10 \\
-.54\end{array}$ \\
\hline $\begin{array}{l}\text { Najas indica } \\
\text { Halophila beccarii } \\
\text { Halodule uninervis } \\
\text { Halophila ovalis }\end{array}$ & Foliar C:N & $\begin{array}{l}-.06 \\
.22 \\
.25 \\
.77^{*}\end{array}$ & $\begin{array}{r}.01 \\
-.04 \\
-.01 \\
.17\end{array}$ & $\begin{array}{l}.07 \\
.40^{*} \\
.41 \\
.16\end{array}$ & $\begin{array}{r}-.01 \\
.25 \\
-.38 \\
.45\end{array}$ & $\begin{array}{l}-.38 \\
-.44^{*} \\
.24 \\
-.25\end{array}$ & $\begin{array}{r}.25 \\
-.06 \\
.12 \\
.47\end{array}$ & $\begin{array}{l}.43^{*} \\
-.01 \\
.16 \\
.22\end{array}$ & $\begin{array}{r}-.38 \\
-.13 \\
-.10 \\
.01\end{array}$ & $\begin{array}{r}.06 \\
.10 \\
-.18 \\
-.50\end{array}$ & $\begin{array}{l}-.07 \\
-.16 \\
-.23 \\
-.30\end{array}$ & $\begin{array}{r}-.10 \\
.00 \\
-.37 \\
.66\end{array}$ & $\begin{array}{l}.43^{*} \\
.13 \\
. .16 \\
.64\end{array}$ & $\begin{array}{r}-.39 \\
-.12 \\
.07 \\
-.54\end{array}$ \\
\hline $\begin{array}{l}\text { Najas indica } \\
\text { Halophila beccarii } \\
\text { Halodule uninervis } \\
\text { Halophila ovalis }\end{array}$ & Foliar C:P & $\begin{array}{l}-.28 \\
-.13 \\
-.18 \\
-.32\end{array}$ & $\begin{array}{r}.08 \\
.06 \\
-.46 \\
.10\end{array}$ & $\begin{array}{r}.01 \\
-.22 \\
.17 \\
-.38\end{array}$ & $\begin{array}{l}.12 \\
-.06 \\
-.60^{* *} \\
-.20\end{array}$ & $\begin{array}{l}-.12 \\
.01 \\
.32 \\
.20\end{array}$ & $\begin{array}{l}-.25 \\
-.19 \\
-.04 \\
-.14\end{array}$ & $\begin{array}{r}.15 \\
-.03 \\
.09 \\
-.12\end{array}$ & $\begin{array}{r}-.26 \\
-.13 \\
-.12 \\
.08\end{array}$ & $\begin{array}{r}.20 \\
-.13 \\
.01 \\
-.23\end{array}$ & $\begin{array}{l}-.49^{*} \\
-.12 \\
-.06 \\
.09\end{array}$ & $\begin{array}{r}.12 \\
.38 \\
-.36 \\
-.11\end{array}$ & $\begin{array}{r}.18 \\
.01 \\
-.25 \\
-.47\end{array}$ & $\begin{array}{l}-.03 \\
.30 \\
.15 \\
.69\end{array}$ \\
\hline $\begin{array}{l}\text { Najas indica } \\
\text { Halophila beccarii } \\
\text { Halodule uninervis } \\
\text { Halophila ovalis }\end{array}$ & Foliar N:P & $\begin{array}{l}-.13 \\
-.25 \\
-.39 \\
-.58\end{array}$ & $\begin{array}{c}.04 \\
.07 \\
-.48^{*} \\
.01\end{array}$ & $\begin{array}{l}-.05 \\
-.43^{*} \\
-.16 \\
-.38\end{array}$ & $\begin{array}{l}.08 \\
-.20 \\
-.32 \\
-.34\end{array}$ & $\begin{array}{l}.23 \\
.25 \\
.15 \\
.26\end{array}$ & $\begin{array}{l}-.36 \\
-.15 \\
-.14 \\
-.31\end{array}$ & $\begin{array}{r}-.25 \\
-.03 \\
.03 \\
-.19\end{array}$ & $\begin{array}{r}.14 \\
-.05 \\
-.05 \\
.06\end{array}$ & $\begin{array}{r}.08 \\
-.17 \\
.15 \\
.01\end{array}$ & $\begin{array}{r}-.26 \\
-.03 \\
.13 \\
.20\end{array}$ & $\begin{array}{r}.15 \\
.36 \\
-.08 \\
-.36\end{array}$ & $\begin{array}{l}-.22 \\
-.06 \\
-.14 \\
-.65\end{array}$ & $\begin{array}{l}.29 \\
.35 \\
.11 \\
.79^{* *}\end{array}$ \\
\hline $\begin{array}{l}\text { Najas indica } \\
\text { Halophila beccarii } \\
\text { Halodule uninervis } \\
\text { Halophila ovalis }\end{array}$ & Foliar $\delta^{13} \mathrm{C}$ & $\begin{array}{l}.15 \\
-.20 \\
-.53^{*} \\
-.03\end{array}$ & $\begin{array}{l}-.34 \\
.03 \\
-.67^{* *} \\
.08\end{array}$ & $\begin{array}{l}.37 \\
.50^{* *} \\
.57^{*} \\
.62\end{array}$ & $\begin{array}{r}.32 \\
.07 \\
-.34 \\
.05\end{array}$ & $\begin{array}{l}.01 \\
-.33 \\
-.06 \\
-.14\end{array}$ & $\begin{array}{r}.20 \\
-.01 \\
-.29 \\
.35\end{array}$ & $\begin{array}{l}.06 \\
-.16 \\
-.25 \\
-.61\end{array}$ & $\begin{array}{l}.00 \\
.13 \\
.14 \\
.91^{* *}\end{array}$ & $\begin{array}{l}.06 \\
-.11 \\
-.38 \\
-.10\end{array}$ & $\begin{array}{r}.06 \\
-.27 \\
.29 \\
.21\end{array}$ & $\begin{array}{r}-.04 \\
-.15 \\
-.17 \\
.55\end{array}$ & $\begin{array}{r}.05 \\
-.09 \\
-.18 \\
.48\end{array}$ & $\begin{array}{r}-.11 \\
.05 \\
.13 \\
-.49\end{array}$ \\
\hline $\begin{array}{l}\text { Najas indica } \\
\text { Halophila beccarii } \\
\text { Halodule uninervis } \\
\text { Halophila ovalis }\end{array}$ & Foliar $\delta^{15} \mathbf{N}$ & $\begin{array}{l}.10 \\
-.08 \\
-.55^{*} \\
-.33 \\
\end{array}$ & $\begin{array}{l}.16 \\
-.11 \\
-.51^{*} \\
.19 \\
\end{array}$ & $\begin{array}{l}-.58^{*} \\
.02 \\
.23 \\
-.31\end{array}$ & $\begin{array}{l}-.54^{* *} \\
-.42^{*} \\
-.42 \\
-.70\end{array}$ & $\begin{array}{l}.48^{*} \\
.08 \\
.20 \\
.38\end{array}$ & $\begin{array}{l}-.42^{*} \\
.03 \\
-.27 \\
-.01\end{array}$ & $\begin{array}{l}-.50^{*} \\
-.09 \\
-.14 \\
.16 \\
\end{array}$ & $\begin{array}{r}.38 \\
.14 \\
.03 \\
-.13 \\
\end{array}$ & $\begin{array}{r}-.16 \\
.03 \\
-.24 \\
.28 \\
\end{array}$ & $\begin{array}{r}.25 \\
.04 \\
.35 \\
-.09\end{array}$ & $\begin{array}{l}-.09 \\
-.08 \\
-.40 \\
-.41\end{array}$ & $\begin{array}{l}-.30 \\
-.25 \\
-.08 \\
-.78^{*} \\
\end{array}$ & $\begin{array}{r}.21 \\
.22 \\
. .07 \\
.88 \\
\end{array}$ \\
\hline
\end{tabular}

made maps of sampling sites and spatial distribution of key environmental variables. K.K. contributed to the evaluation of the variation in $\delta^{13} \mathrm{C}$ and $\delta^{15} \mathrm{~N}$ of macrophytes. D.T.N.Y. and H.O.V. wrote the manuscript with contributions from all co-authors.

\section{ACKNOWLEDGEMENTS}

The study was funded by grants of the Belgian Government (VLIR-UOS) and the Graduate School of Global Environmental Studies (GSGES Seeds, Kyoto University, Japan). I am grateful to various students of the Faculty of Environmental Sciences of Hue University of Sciences (Vietnam) for their assistance with the field and lab activities. Stable isotope facilities were supported by grants from FWO Hercules (HERC46) and VUB SRP2: Tracing and modelling of present and ancient global changes.

\section{LITERATURE CITED}

Andersen, J.M. 1976. An ignition method for determination of total phosphorus in lake sediments. Water Research 10: 329-331.

Anderson, W.T. \& J.W. Fourqurean 2003. Intra- and interannual variability in seagrass carbon and nitrogen stable isotopes from south Florida, a preliminary study. Organic Geochemistry 34: 185-194.
APHA: American Public Health Association 1999. Standard Methods for the Examination of Water and Wastewater, 20th edition. American Public Health Association, American Water Works Association, Water Environment Federation, Washington DC.

Apostolaki, E.T., M. Holmer, N. Marbà \& I. Karakassis 2011. Reduced carbon sequestration in a Mediterranean seagrass (Posidonia oceanica) ecosystem impacted by fish farming. Aquaculture Environment Interactions 2:49-59.

Atkinson, M. \& S. Smith 1983. C:N:P ratios of benthic marine plants. Limnology and Oceanography 28: 568-574.

Beer, S., M. Bjork, F. Hellblom \& L. Axelsson 2002. Inorganic carbon utilization in marine angiosperms (seagrasses). Functional Plant Biology 29:349-354.

Borum, J., O. Pedersen, L. Kotula, M.W. Fraser, J. Statton, T.D. Colmer \& G.A. Kendrick 2016. Photosynthetic response to globally increasing $\mathrm{CO}_{2}$ of co-occurring temperate seagrass species. Plant, Cell and Environment 39:1240-1250.

Burkholder, J.M., D.A. Tomasko \& B.W. Touchette 2007. Seagrasses and eutrophication. Experimental Marine Biology and Ecology 350:46-72.

Campbell, J.E. \& J.W. Fourqurean 2009. Interspecific variation in the elemental and stable isotope content of seagrasses in South Florida. Marine Ecology Progress Series 387:109-123. 
Campbell, J.E. \& J.W. Fourqurean 2013. Mechanisms of bicarbonate use influence the photosynthetic carbon dioxide sensitivity of tropical seagrasses. Limnology and Oceanography 58:839-848.

Cao, V.L., V.T. Nguyen, T. Komatsu, D.V. Nguyen \& D.T. Dam 2012. Status and threats on seagrass beds using GIS in Vietnam. SPIE-Remote Sensing of the Marine Environ ment II.http://dx.doi.org/10.1117/12.977277. p. 8525 12. Last accessed 20.09.2019.

Carlson, R.E. 1977. A trophic state index for lakes. Limnology and Oceanography 22:361-369.

Chappuis, E., V. Seriñá, E. Martí, E. Ballesteros \& E. Gacia 2017. Decrypting stable isotope $\left(\delta^{13} \mathrm{C}\right.$ and $\left.\delta^{15} \mathrm{~N}\right)$ variability in aquatic plants. Freshwater Biology 62(11):1-12.

Connolly, R.M., D. Gorman, J.S. Hindell, T.N. Kildea \& T.A. Schlacher 2013. High congruence of isotope sewage signals in multiple marine taxa. Marine Pollution Bulletin 71: 152-158.

Daya A.A. \& H. Bejari 2015. A comparative study between simple kriging and ordinary kriging for estimating and modeling the $\mathrm{Cu}$ concentration in Chehlkureh deposit, SE Iran. Arabian Journal of Geosciences 8:6003-6020.

Disperati, L. \& S.G.P. Virdis 2015. Assessment of land-use and land-cover changes from 1965 to 2014 in Tam GiangCau Hai Lagoon, central Vietnam. Applied Geography 58: 48-64.

Duarte, C.M. 1990. Seagrass nutrient content. Marine Ecology Progress Series 67:201-201.

Estefan, G., R. Sommer \& J. Ryan 2014. Analytical Methods for Soil, Plant and Water in the Dry Areas: A manual of Relevance to the West Asia and North Africa Region, Third Edition. International Center for Agriculture research in the Dry Areas, Aleppo, 255 pp.

Falkowski, G.D. Farquhar, J.R. Ehleringer \& K.T. Hubick 1989. Carbon isotope discrimination and photosynthesis. Annual Review of Plant Physiology and Plant Molecular Biology 40:503-537.

Ferdie, M. \& J.W. Fourqurean 2004. Responses of seagrass communities to fertilization along a gradient of relative availability of nitrogen and phosphorus in a carbonate environment. Limnology and Oceanography 49:2082-2094.

Fourqurean, J.W., S.A. Manuel, K.A. Coates, W.J. Kenworthy \& J.N. Boyer 2015. Water quality, isoscapes and stoichioscapes of seagrasses indicate general P limitation and unique $\mathrm{N}$ cycling in shallow water benthos of Bermuda. Biogeosciences 12:6235-6249.

Fourqurean, J.W., N. Marba, C.M. Duarte, E. Diaz-Almela \& S. Ruiz-Halpern 2007. Spatial and temporal variation in the elemental and stable isotopic content of the seagrasses Posidonia oceanica and Cymodocea nodosa from the Illes Balears, Spain. Marine Biology 151:219-232.

Fourqurean, J.F., T.O. Moore, B. Fry \& J.T. Hollibaugh 1997. Spatial and temporal variation in C:N:P ratios, $\delta^{15} \mathrm{~N}$, and $\delta^{13} \mathrm{C}$ of eelgrass Zostera marina as indicators of ecosystem processes, Tomales Bay, California, USA. Marine Ecology Progress Series 157:147-157.

Fraser, M.W., G.A. Kendrick, P.F. Grierson, J.W. Fourqurean, M.A. Vanderklift \& D.I. Walker 2012. Nutrient status of seagrasses cannot be inferred from system-scale distribution of phosphorus in Shark Bay, Western Australia. Marine and Freshwater Research 63:1015-1026.

Fry, B. 2002. Conservative mixing of stable isotopes across estuarine salinity gradients: a conceptual framework for monitoring watershed influences on downstream fisheries production. Estuaries and Coasts 25:264-271.

Geovariances 2016. ISATIS Software: Technical References Release 2016.1. Geovariances \& Ecole des Mines de Paris, Paris, France.

Goovaerts P (1997) Geostatistics for Natural Resources Evaluation. Oxford University Press, New York.

Gordon, D.M., P.B. Birch \& A.J. McComb 1981. Effects of inorganic phosphorus and nitrogen on the growth of an estuarine Cladophora in culture. Botanica Marina 24: 93-106.

Gorman, D., A. Turra, R.M. Connolly, A.D. Olds \& T.A. Schlacher 2017. Monitoring nitrogen pollution in seasonally-pulsed coastal waters requires judicious choice of indicator species. Marine Pollution Bulletin 122:149-155.

Hemminga, M.A. \& M.A. Mateo 1996. Stable carbon isotopes in seagrass: variability in ratios and use in ecological studies. Marine Ecology 140:285-298.

Herbeck, L.S., M. Sollich, D. Unger, M. Holmer \& T.C. Jennerjahn 2014. Impact of pond aquaculture effluents on seagrass performance in NE Hainan, tropical China. Marine Pollution Bulletin 85:190-203.

Hitchcock, J.K., S.C. Courtenay, M.R.S. Coffin, C.C. Pater \& M.R. van Den Heuvel 2017. Eelgrass bed structure, leaf nutrient, and leaf isotope responses to natural and anthropogenic gradients in estuaries of the Southern Gulf of St. Lawrence, Canada. Estuaries and Coasts 40:1653-1665.

Hobbie, E., A. Jumpponen \& J. Trappe 2005. Foliar and fungal ${ }^{15} \mathrm{~N}:{ }^{14} \mathrm{~N}$ ratios reflect development of mycorrhizae and nitrogen supply during primary succession: testing analytical models. Oecologia 146:258-268.

Hoyer, M.V., T.K Frazer., S.K. Notestein \& D.E. Canfield 2004. Vegetative characteristics of three low-lying Florida coastal rivers in relation to flow, light, salinity and nutrients. Hydrobiologia 528:31-43.

Invers, O., M. Perez \& J. Romero 1999. Bicarbonate utilization in seagrass photosynthesis: role of carbonic anhydrase in Posidonia oceanica (L) Delile and Cymodocea nodosa (Ucria) Ascherson. Journal of Experimental Marine Biology and Ecology 235:125-133.

Johengen, T. 1997. Standard operating procedures for determining total phosphorus, available phosphorus, and biogenic silica concentrations of Lake Michigan sediments and sediment trap material, in Lake Michigan mass balance study (LMMB) methods compendium. In: Metals, conventionals, radiochemistry and biomonitoring sample analysis techniques, vol. 3, (L. Blume, ed.), pp. 305-312, United States Environmental Protection Agency (EPA 905R97012c).

Johnson, M.W., K.L Heck \& J.W. Fourqurean 2006. Nutrient content of seagrasses and epiphytes in the northern Gulf of Mexico: Evidence of phosphorus and nitrogen limitation. Aquatic Botany 85:103-111.

Keeley, J.E. \& D.R. Sandquist 1992. Carbon: freshwater plants. Plant, Cell and Environment 15:1021-1035.

Kratzer, C.R. \& P.L. Brezonik 1981. A carlson-type trophic state index for nitrogen in florida lakes. Water Resources Bulletin 17:713-715.

Le, X.T. 2012. Preliminary assessment of sea level rise impacts to coastal ecosystems in Thua Thien-Hue. VNU Journal of Science, Earth Sciences 28:140-151.

Lepoint, G., P. Dauby \& S. Gobert 2004. Applications of C and $\mathrm{N}$ stable isotopes to ecological and environmental studies in seagrass ecosystems. Marine Pollution Bulletin 49: 887-891. 
Lepoint, G., B. Frederich, S. Gobert \& E. Parmentier 2008. Isotopic ratios and elemental contents as indicators of seagrass $\mathrm{C}$ processing and sewage influence in a tropical macrotidal ecosystem (Madagascar, Mozambique Channel). Scientia Marina 72:109-117.

Logan, M. 2010. Biostatistical design and analysis using R: $A$ practical guide. Wiley \& Blackwell, England, 557 pp.

Michener, R.H. \& K. Lajtha 2007. Stable isotopes in ecology and environmental science. Blackwell Scientific Publications, Oxford, 592 pp.

Mook, W.G. 2000. Environmental isotopes in the bydrological cycle: principles and applications, vol. 1: Introduction; theory, methods, review. IHP-V Technical documents in hydrology. No 39, Vol. I. UNESCO, Paris.

Murphy, J. \& J.P. Riley 1962. A modified single solution method for the determination of phosphate in natural waters. Analytica Chimica Acta 27:31-36.

Nguyen, Q.C.T. \& M. Yabe 2014. Shrimp poly-culture development and local livelihoods in Tam Giang-Cau Hai Lagoon, Vietnam. Agricultural Science 6:1-14.

Odelu, G., N.M. Kumar, N. Siddulu \& K. Raghu 2014. Enumeration of macrophytes of eutrophicated and noneutrophicated lakes of two tahasils of Karim Nagar District. Biolife 2:1170-1180.

Oksanen, J., G.F. Blanchet, R. Kindt, P. Legendre, P.R. Minchin, R.B. O’Hara, G.L. Simpson, P. Solymos, M.H.H. Stevens \& H. Wagner 2013. vegan: Community Ecology Package. $\mathrm{R}$ package version 2.0-9. Available at :http://cran.rproject.org $/$ package $=$ vegan.

Paerl, H 2009. Controlling eutrophication along the freshwater - marine continuum: dual nutrient $(\mathrm{N}$ and $\mathrm{P})$ reductions are essential. Estuaries and Coasts 32:593-601.

Peipoch, M., E. Gacia, A. Blesa, M. Ribot, J.L. Riera \& E. Martí 2014. Contrasts among macrophyte riparian species in their use of stream water nitrate and ammonium: insights from ${ }^{15} \mathrm{~N}$ natural abundance. Aquatic Sciences 76:203-215.

Phan, T.T.H. 2018. Submerged aquatic vegetation in a tropical lagoon environment: Dynamics and resilience strategy. $\mathrm{PhD}$ thesis, Vrije Universiteit Brussels, Belgium. 193 pp.

R Core Team 2017. R: A language and environment for statistical computing. R Foundation for Statistical Computing, Vienna, Austria.

Raven, J.A., A.M Johnston, J.E Kübler, R. Korb, S.G. McInroy, L.L. Handley, C.M. Scrimgeour, D.I. Walker, J. Beardall, M. Vanderklift, S. Fredriksen \& K.H. Dunton 2002. Mechanistic interpretation on carbon isotope by marine macroalgae and seagrasses. Functional Plant Biology 29:355-378.

Risk, M.J., B.E. Lapointe, O.A. Sherwood \& B.J. Bedford 2009. The use of $\delta^{15} \mathrm{~N}$ in assessing sewage stress on coral reefs. Marine Pollution Bulletin 58:793-802.

Schmidt, A.L., J.K.C. Wysmyk, S.E. Craig \& H.K. Lotze 2012. Regional-scale effects of eutrophication on ecosystem structure and services of seagrass beds. Limnology and Oceanography 57:1389-1402.

Schwarz, A.M., M. Björk, T. Buluda, H. Mtolera \& S. Beer 2000. Photosynthetic utilisation of carbon and light by two tropical seagrass species as measured in situ. Marine Biology 137:755-761.

Shilla, D.A., T. Asaeda, S. Kian, R. Lalith \& J. Manatunge 2006. Phosphorus concentration in sediment, water and tissues of three submerged macrophytes of Myall Lake, Australia. Wetlands Ecology and Management 14:549-558.
Short, F.T., B. Polidoro, S.R. Livingstone, K.E. Carpenter, S. Bandeira, J.S. Bujang, H.P. Calumpong, T.J.B. Carruthers, R.G. Coles, W.C. Dennison, P.L.A Erftemeijer, M.D. Fortes, A.S. Freeman, T.G. Jagtap, A.H.M. Kamal, G.A. Kendrick, W. Judson Kenworthy, Y.A. La Nafie, I.M. Nasution, R.J. Orth, A. Prathep, J.C. Sanciangco, B. van Tussenbroek, S.G. Vergara, M. Waycott \& J.C. Zieman 2011. Extinction risk assessment of the world's seagrass species. Biological Conservation 144:1961-1971.

Schmidt, M., H.S. Windisch, K.U. Ludwichowski, S.L.L. Seegert, H.O. Portner, D. Storch \& C. Bock 2018. Seawater carbonate chemistry and neurochemical profiles of two gadid species. PANGAEA. https://doi.org/10.1594/ PANGAEA.892312.

Stapel, J. \& M.A. Hemminga 1997. Nutrient resorption from seagrass leaves. Marine Biology 128:197-206.

Sun, Z., X. Mou, X. Li, L. Wang, H. Song \& H. Jiang 2011. Application of stable isotope techniques in studies of carbon and nitrogen biogeochemical cycles of ecosystem. Chinese Geographical Science 21:129-148.

Thanh, T.D., Y. Saito, V.D. Huy, V.L. Nguyen, T.K.O. Ta \& M. Tateishi 2004. Regimes of human and climate changes in Vietnam. Regional Environmental Change 4:49-62.

Udy, U.W \& W.C. Dennison 1997. Growth and physiological responses of three seagrass species to elevated sediment nutrients in Moreton Bay, Australia. Experimental Marine Biology and Ecology 217:253-277.

Uku, J., S. Beer \& M. Bjork 2005. Buffer sensitivity of photosynthetic carbon utilisation in eight tropical seagrasses. Marine Biology 147:1085-1090.

Van Katwijk, M.M., M.E.W. Van der Welle, E.C.H.E.T. Lucassen, J.A. Vonk, M.J.A. Christianen, K.W. HakimI, A. Arifin, T.J. Bouma, J.G.M. Roelofs \& L.P.M. Lamers 2011. Early warning indicators for river nutrient and sediment loads in tropical seagrass beds: a benchmark from a nearpristine archipelago in Indonesia. Marine Pollution Bulletin 62:1512-1520.

Vizzini, S. \& A. Mazzola 2004. Stable isotope evidence for the environmental impact of a land-based fish farm in the western Mediterranean. Marine Pollution Bulletin 49: 61-70.

Walton, M.E.M., I. Al-Maslamani, N. Haddaway, H. Kennedy \& A. Castillo 2016. Extreme ${ }^{15} \mathrm{~N}$ depletion in seagrasses. Estuaries and Coasts 39:1709-1723.

Waycott, M., C.M. Duarte, T.J.B. Carruthers, R.J. Orth, W.C. Dennison, S. Olyarnik, A. Calladine, J.W. Fourqurean, K.L. Heck Jr., A. Randall Hughes, G.A. Kendrick, W.J. Kenworthy, F.T. Short \& S.L. Williams 2006. Accelerating loss of seagrasses across the Globe threatens coastal ecosystems. PNAS 106(30):12377-12381.

West, J.B., G.J. Bowen, T.E. Cerling \& J.R. Ehleringer 2006. Stable isotopes as one of nature's ecological recorders. Trends in Ecology and Evolution 21:408-414.

Whalen, M.A., J.E. Duffy \& J.B. Grace 2013. Temporal shifts in top-down vs. bottom-up control of epiphytic algae in a seagrass ecosystem. Ecology 94:510-520.

Yamamuro, M., H. Kayanne \& H. Yamano 2003. $\delta^{15} \mathrm{~N}$ of seagrass leaves for monitoring anthropogenic nutrient increases in coral reef ecosystems. Marine Pollution Bulletin 46:452-458.

Yu, H., Z. Yu, X. Song, X. Cao, Y. Yuan \& G. Lu 2015. Seasonal variations in the nitrogen isotopic composition of dissolved nitrate in the Changiiang River estuary, China. Estuarine, Coastal and Shelf Science 155:148-155. 